\title{
Moving to the Rhythm of Africa: a Case Study of a Tertiary Educator's Understanding of Multicultural Dance in Teacher Education
}

\author{
Dawn Joseph ${ }^{1}$ \\ ${ }^{1}$ Faculty of Arts and Education, Deakin University, Melbourne, Australia \\ Correspondence: Dawn Joseph, Deakin University, 221 Burwood Highway, Burwood, 3125, Victoria. Australia. \\ Tel: 61-3-9244-6284. E-mail: djoseph@deakin.edu.au
}

Received: February 2, 2013 Accepted: February 18, 2013 Available online: March 3, 2013

doi:10.11114/jets.v1i1.82

URL: http://dx.doi.org/10.11114/jets.v1i1.82

\begin{abstract}
Australia is proud of its rich and varied array of the Arts depicting a range of cultural diversity formed by ongoing migration. Although the complex issues of dance, culture and identity are interconnected, forming a multicultural society in Australia, dance education is a powerful platform to transmit and promote togetherness where understanding and respect is shared in dance practice. The focus of this article is on dance education as part of multicultural arts education within teacher education courses at Deakin University (Melbourne) Australia. It forms part of my ongoing wider study that started in 2010 regarding Attitudes and perceptions of Arts Education Students: Preparing culturally responsive teachers across two continents (Australia and South Africa). In 2011, I interviewed the dance educator and will report on two themes from her interview data: multicultural dance and the inclusion of African dance within multicultural dance practice. I argue that the inclusion of innovative and immersive practice of dance where authentic teaching and learning can be facilitated is a powerful platform to share multicultural dance practice in tertiary education.
\end{abstract}

Keywords: dance education, African Dance, multicultural dance education, teacher education, curriculum and culturally responsive pedagogy

\section{Introduction}

Education serves as an effective vehicle to explore and expand our ways of understanding and knowing about 'others' and 'self' through Arts education (dance, drama, media, music and visual arts). According to the Australian Curriculum, Assessment and Reporting Authority (ACARA, 2012a) although each of the Art forms are discrete, they have overarching connections between them. The $2^{\text {nd }}$ draft document for the new national curriculum in Australia recognises that through making and responding in the Arts, students will need access to the Arts. ACARA points out that students will understand how the Arts connects to their social, cultural and historical context (ACARA, 2012a). My study is situated at a tertiary institute in Melbourne (Victoria). Victoria is said to be the most multicultural state in Australia with a history that was "forged on successive waves of migration" (Victorian Multicultural Commission 2009). Arts educators at all levels of education continue to be challenged by the changing demographics of students. It is therefore necessary to be inclusive and cognizant of this change in our range of teaching activities and content as Stodolsky and Grossman rightly point out in their research "diversity does not equal deficit" $(2000, p .2)$. The $2^{\text {nd }}$ draft ACARA document for the Arts reiterates that through the Arts students will learn the works of diverse cultures thereby gaining an intercultural understanding of others (ACARA, 2012a). As a tertiary music educator, I bring to my classes my culture, bias and often my 'Western' training; likewise, students enter our classrooms with their own culture, language and bias. Hence, we need to be culturally responsive to our students' at all educational levels. Richards, Brown and Forde (2007) point out that as teachers we need to provide a teaching environment that is welcoming and supportive, where there is optimal provision for learning opportunities to take place.

This article focuses on Dance Education at Deakin University (Faculty of Arts and Education) as part of the teacher education courses. Dance and Music is in a good position to break down what Wade (1998) refers to as 'brick walls' where students' preconceived attitudes prevent them from understanding and valuing diversity when learning about different music and dances. Within the ACARA draft document, dance education "engages 
students with knowledge and understanding of diverse cultures and contexts enhancing their personal, social and cultural identity" (ACARA, 2012a, p.24). Currently, each of the eight major Australian states and territories continues to work from a separate state curriculum where dance forms part of the domain of the Arts. In the case of Victoria, the Victorian Essential learning Standards (VELS) is the official curriculum where dance falls under the domain of the performing Arts. Modest direction is given to teachers in the Arts as the curriculum only offers a framework for schools (years preparatory to 10). In the state of Victoria not all schools employ dance teachers as part of the performing arts curriculum as most schools offer either visual arts and or music. The choice of the 'Arts' at schools is dependent on the principal, staffing, resources and facilities. All schools do include the Arts in their curriculum as the Arts have the potential "to deliver and show important benefits to both the individual and society" (Dinham, 2011, p21). According to Duncan (2011) "experiences in the arts are valuable on their own, but they also enliven learning of other subjects, making them indispensable for a complete education in the 21st Century”. Within the performing Arts, dance education help students explore realities, relationships, and ideas that cannot be conveyed simply in words or numbers (Melchior, 2011).

Engagement particularly in the performing Arts means that our sense of time and place exists within a multicultural space as we presently find ourselves in a "world saturated with imagery, sounds and performances" (VELS, 2011). In my ongoing research I have found that by including a new and different genre like that of African music and culture in both school and university settings, students gain a better understanding of others and of difference in relation to music, people and culture (Joseph, 2002, 2003, 2005 \& 2006). Writing specifically about dance education, Robinson and Domenici (2010) propose that university dance programs have an intercultural approach to dance education, they suggest a focus on history and cultures when teaching dance so that students may engage in dialogue and debate. It is through such dialogue that we create spaces for intercultural understandings as we "so-reflect" (Tyler, 2009, p 142). Tyler (2009) is of the opinion that by reflecting "the group is more fully aware of the reasons behind what might otherwise escalate into debate rather than dialogue (p.142). Robinson and Domenici (2010) recognise "if we don't quickly find a way to move beyond Western-focused models, the education we offer students will become increasingly irrelevant and obsolete" (p.216). Similarly Nieto (1992) rightly argues "we do our students a disservice when we prepare them to live in a society that no longer exists” (p.281).

\subsection{Dance Education Context}

Dance education may be considered a field of artistic expression within the Arts. When preparing dance education programs that are less Euro-centric, we not only increase our students' expertise, we also draw upon them. In this way "all identities and differences are seen as being worthy of affirmation" (Merton, 2011, p.24) thereby opening up doors of dialogue which do not exclude or marginalise difference. According to Melchior (2011, p.111) "dance has an important place in multicultural education and the development of culturally responsive pedagogy". Similarly, this article resonates with Melchoir (2011) who argues that through dance, children can explore and express their own and other's cultures and share stories in ways other than the spoken and written word” (p.121).

My article reports on interview data from a wider study that started in 2010 Attitudes and perceptions of Arts Education Students: Preparing culturally responsive teachers across two continents (Australia and South Africa). It focuses on dance education as part of multicultural arts education within teacher education courses at Deakin University (Melbourne) Australia. Deakin University is the only tertiary institute that offers dance education as a specialism for secondary schools within the Bachelor of Arts/Bachelor of Teaching (Secondary) (BA/BTeach) and the Master of Teaching (MTeach) courses in the state of Victoria. For this reason I draw only on interview data (2011) with the dance educator from this university to argue that dance education can be seen as an agent of social change, a powerful dais to alter perceptions, attitudes and beliefs in our teacher education courses and in our future teachers. By providing rich multicultural programs for our pre-service students in dance education including that of African, we can foster positive experiences that promote diversity and enhance intercultural and cross-cultural understanding. I align my notion of intercultural to that of Gareis (1995) who argues "situations involving two or more cultures...from two different backgrounds" (p.3). This as Dunne (2011), rightly points out is a straightforward idea "underpinned by the much more problematic and nebulous concept of culture" (p.610). I am not focusing my discussion on the complexities of such concepts rather I wish to draw the reader's attention to the multicultural society in which we find ourselves in Melbourne and focus on the rich opportunities we can create for our students within our tertiary education programs. According to Dinham (2011), "learning about different dances, children come to understand, in a visceral way, the history, values and customs of different cultures” (p.249). I argue that the inclusion of innovative and immersive practice, in particular of African dance where authentic teaching and learning can be facilitated, is a powerful platform to share multicultural dance 
practice in tertiary education. The dance educator is born in Australia; she has over twenty years of tertiary experience in the area of teacher education. She is one of the few dance tertiary lecturers within teacher education courses in Australia that provides a focus on African dance.

\subsection{Theoretical Underpinnings}

According to the Multicultural Arts Victoria Annual Report (2010, p.4), "the arts [dance] are great catalysts that connect people in a deep and powerful way". Not only do the arts transcend social, cultural and linguistic barriers, it is hoped that people through their engagement with multicultural dance will have a "greater cultural appreciation, understanding and respect" for each other in the wider community (Multicultural Arts Victoria Annual Report, 2010,p.4). It may be argued, "communities that embrace diversity, creative expression and cultural activity are richer, stronger and better able to deal with social challenges” (Pope \& Doyle2006).

While there is a plethora of scholarly opinions around the notion there is more to dance than just physical movement and learning steps. Research has shown that the teaching of cultural and historical context in dance is imperative and is a useful space to learn of other cultures to enhance students learning (Buck, 2003, Chappell, et al. 2009 \& Melchior, 2011). Mushi (2004) asserts, "teachers must consider cultural diversity" (p.180) in their practice as a vibrant and important part of multiculturalism. Multiculturalism is a social construct that draws on the exploration of others and not just our own culture, art, sciences and ethics (Burbules 1997). Within dance teacher education programs at tertiary level we have the chance to be reflective of the wider multicultural society we live in and provide opportunities for our students to engage, experience and explore the wide array of cultures and dance. In so doing, Melchoir (2011) believes "students develop an awareness and understanding of dance in historical and contemporary contexts" (p.121). This resonates with Chappell (2009) and others notion of dance teaching and learning as a "social meaning-making process rather than [a] transmission activity" (p.38). In this way Hayes affirms (2010) "teachers have the opportunity to influence the lives and chances of young people...not only do they shape what people learn, but also what they value, believe and understand" (p.1). By exploring and engaging in our own and others Arts "we deepen our knowledge and understanding of them" (Russell-Bowie, 2009, p.4) and through using movement "new ways of seeing things, new ways of thinking and therefore new ways of knowing the world" can be explored through dance (Hong, 2000, p.2 cited in Melchoir, 2011, p.126). The challenge for us as tertiary arts educators is how best can we do this and also prepare our pre-service teachers to be culturally responsive which Villegas \& Lucas (2002) point out can be "complex and demanding” (p.177).

Africa is the second largest continent with 54 countries; over 3000 ethnic groups speaking over 2000 languages (Zijlma 2011), it is impossible to know all its music, dance and culture. Therefore it is not possible to prepare dance education students to become fully enculturated into all of them. The continent is as diverse as its people, I align my use of the terms African dance and culture to Mills' (1994) understanding "as a generalisation that encompasses both traditional and contemporary forms of expression on the continent of Africa and throughout the African diaspora (p.36). In Africa, music and dance are inseparable "no one can claim to know everything about music in Africa. African cultures are so diverse and so is their music" (Miya, 2003, p.2). Similarly, Risner (2007) writing specifically about dance education points out that the vastness of dance in the continent "can provide a fertile environment that encourages males and females to express themselves" in a diverse socio-cultural context (p.970). In African societies, song and dance is the medium through which children and young people receive instruction about traditional customs and practices, obligations and responsibilities. Drumming and percussion instruments (djembe, cow-bell, gankoqui double bell, rattle and sheker shaker) are central to most parts of Africa where music plays an important part in providing the rhythm and beat for dance. This aspect is beyond the scope of this article and is not discussed here. Rather I stress the importance that music plays in African dance. The music not only provides an accompaniment for dance, drummers improvise and so do the dancers as they have conversation with each other. Through music and dance a sense of community begins to form bringing dancer, musician and audience together. I use the IsiZulu word Ubuntu ${ }^{i}$ (I am because of another), a philosophical concept which is fundamental to African life and culture where "a person is a person by virtue of other people" (Oehrle and Emeka, 2003, p.39) to make the link of interconnections between music, dance and community in African society.

\subsection{Background: VELS and Dance Education Units}

It can be argued that the way we teach and what we teach are largely influenced by our individual culture, identity and training. Our differences and the lived experience that we either acquire or own, contribute to the rich array of understandings in our teaching as we use it as a frame to interpret and appreciate new dances and the societies from which they come. If the teaching "is participatory, inclusive and responsive" then this "will 
enable minority students to maintain their culture heritage as well as fulfil their educational potential" (Mansouri, et al., 2009, p.11). Within the Victorian Essential Learning Standards (VELS) there is scope for such to occur. Such implementation and inclusion is entirely dependent on individual dance teachers at schools and tertiary dance educators.

Writing specifically about Dance curriculum in Victoria (Australia), there are two dimensions in VELS (2011): 'Creating and Making' ("focuses on making and sharing dance and movement works within the classroom" whereby "sharing can involve talking about movements they [students] are using, why they are using them and how they are communicating meaning through the movements") and 'Exploring and Responding' ("investigate and comment on a diverse range of dance styles, learning about different expressive ways of moving and ways in which the meanings behind movements may change according to cultural and historical context and discuss the importance of dance in their lives and the contribution of different styles of contemporary dance to local and global cultures") (VELS 2012). These dimensions are incorporated within the BA/BTeach and the MTeach where students can specialise as a secondary dance teacher through years 7-12.

There are four methodology units (Arts Discipline Study 1, 2, 3 \& 4) that offer a wide range of curriculum, where students engage in "dance elements, dance making and their application to classroom practice" (Deakin University Handbook 2012a). Within the four units, students also engage in reflective practice and undertake projects in schools and the wider community. As part of multicultural dance practice, Arts Discipline Study 3 pre-service teachers explore and express themselves in a wide range and spectrum of dance styles and genres. In particular students experience and engage in African dance. The handbook for this unit outlines the "choreographic processes and teaching techniques in inter-cultural dance-making” (Deakin University Handbook 2012b). Within this unit, there is a concentration "upon the research and gathering of material (Pan African or Ethnic Dance and its Diaspora) tracing the roots of traditional and indigenous dance and how it has impacted on Western popular culture" (Deakin University Handbook 2012b). Students also engage in "choreographic methods of improvisation, learnt work and group work to facilitate the development of new movement vocabulary and an appreciation of how dance communicates in both a past and present context" and express this in fieldwork and performances which "may also take place at Folkloric associations, cultural nights and multicultural festivals" (Deakin University Handbook 2012b). The assessment for each of the units is directly related to the aims and objectives of the units. As this is beyond the scope of this article I do not discuss this aspect, rather, I focus on the inclusion of African Dance within dance education and in particular the unit Arts Discipline Study 3 entitled: Multicultural Dance.

\section{Methodology}

In 2010 ethics clearance was obtained to undertake a research project Attitudes and perceptions of Arts Education Students: preparing culturally responsive teachers across two continents (Australia and South Africa). Questionnaire and Interviews were undertaken in Australia at Deakin University at the end of September 2010 and in South Africa at the end of October 2010 with both students and tertiary arts educators. This article reports only on interview data with the dance educator in Australia in 2011. The wider study explored how Arts education students and their lecturers (art, dance, drama, media, music, visual communication and design) understand cultural diversity and multicultural arts practice in a changing and often challenging world across the two continents (Australia and South Africa). The interview allowed me to probe and shape questions on issues of culture, multiculturalism, diversity, dance education and teacher education, which led to a richer form of data than the data that might be gained had I done a questionnaire only with the lecturer concerned. Her interview took place in July 2011 and took the form a semi-structured exploratory interview. The interview was taped with her permission and the transcript allowed me to analyse and codify her data into themes. Guba and Lincoln (1981) claim that interviewers are categorised as either structured or 'focused' and unstructured or 'exploratory'. The interview situated itself on a particular topic or theme and allowed for flexibility where the interviewer takes the lead from the interviewee as there are no pre-specified questions (Wilkinson, 2000). Loughran, Mulhall and Berry (2004) conclude from their analysis of literature on expert pedagogy that "teachers' professional knowledge is difficult to categorize and therefore exceptionally difficult to articulate and document” (p.370). Through conversation we were reflective about our practices in African music and African dance as we both embraced common goals of teacher education programs at universities (Greiman and Covington2007). It is "through living and telling...teachers [we] express their [our] personal practical knowledge to themselves [ourselves] and to others” (Craig, 2009, p.602). 


\section{Bringing the Rhythm of Africa into Dance: Findings and Discussion}

\subsection{Background}

In this section of the article I only discuss two themes with the dance educator regarding: multicultural dance and the inclusion of African dance within multicultural dance practice. The dance lecturer has been at Deakin University for over twenty years. As an experienced dance educator (school, tertiary level and community), performer, choreographer and percussionist, she is enthusiastic and passionate about the inclusion of multicultural dance in her dance units, in particular African. In her pre-service dance units (early childhood, primary and secondary) within teacher education courses, she prepares her students to be culturally responsive to multi-ethnic classrooms by providing them with a wide range of styles and genres in dance education. According to Wildmoves (2012), "she has extensively studied dance styles and drumming techniques of the African Diaspora which has led to many exciting artist in residency programs in schools and the community in Australia, Africa and the Netherlands”. Hence the focus of my discussion is on African dance as she continues to undertake ongoing professional development in Africa (particularly in Ghana as well as other parts of West Africa) where she has as a "white dance educator immerse[d] herself in the historical context in order to understand it before she disseminates it" (Kerr-Berry2004: 46). As a tertiary practitioner she has studied and worked with local musicians and dancers onsite in West Africa over the years and has also taken Deakin University tertiary students on school placement to Ghana where they have experienced local Ghanaian education, dance, music and culture.

\subsection{Multicultural Dance}

Writing specifically about dance, the notion of multiculturalism spans a wide spectrum of dances and cultures. Volk (2004) rightly points out "the greater the knowledge one has about the culture, and the expectations or rules of its music [and dance], the greater the understanding or perception of meaning, of that music [and dance] will be” (p.6). The dance lecturer in her interview speaks of her initial classical training and her encounters with African dance. She experienced African dance in a similar vein as Albright (2003) experienced Indian classical dance and refers to it as an embodied approach to teaching across cultures. The dance educator in her interview reports the provision of opportunities and experiences for her students on campus and when off campus (pathways with local communities and festivals) in a similar vein to what Csikszentmihalyi (1990) describes as 'flow' where she links the concept of enjoyment and engagement with learning. Living within a multicultural society in Melbourne, the dance educator in her interview was passionate about providing a multicultural experience to her students. She comments "the more we know of our self and our understanding of where we are and where live in the world, we will not be fearful of anything that is different to us". It was evident in our conversation that she saw dance "as a physical art form" and for her "multiculturalism served as a source of inspiration for trying new ideas, new processes, new ways of looking at things and being influenced by traditional cultures to create something new and contemporary".

Within teacher education courses the dance educator acknowledges the need to prepare students for multicultural, multilingual and multi-ethnic classrooms. She said, "I have always taught from a cultural perspective...You are just mad if you don't get into multiculturalism because human beings are so vast in the way they express themselves". She was adamant that performing Arts educators could make a difference through our practice if we teach from a non-western paradigm. In my area of music education at tertiary level, I have similarly argued that the inclusion of African music is a useful dais from which to learn of the other (Joseph, 2009 \& 2011). Her comment "that is why I am here", positions her as an agent of change within teacher education courses. As change is a multifaceted phenomenon and a prerequisite to improvement Guskey (2002), change, like learning is complex. Imel (2000) supports this view and claims that understanding the relationship between learning and the change process can help adult educators be more purposeful in assisting with change. As the dance educator, she felt she had a "strong intrinsic feeling of 'wow' I can really make a difference and impact curriculum at university level". She found over the years preparing her pre-service teachers to be to culturally responsive is not only a challenge but a necessity "so that is why I like this job. I can teach all about that and my student then goes out with those methods and approaches and develop their own curriculum and make a big impact on their schools".

Although the dance educator recognises the limitations of staff, time, space and resourcing within our tertiary education courses she promotes multicultural dance in an effective way to teach about others. She found "as a dancer we are so much more well equipped if you know many different dance styles not just what you have been trained in". As a classical ballet dancer, she argues, "there are so many different styles within this genre (for example Italian, French and Russian)" hence you learn of the people their culture and that society. She further adds "knowing about folkloric dance and how the average every day person incorporates dance in their everyday 
life be it Greek dancing, or clog dancing is all part of multicultural dance”. Different styles in dance like those in African music contribute to the wide array of multicultural dance and I concur with Jorritsma (2008) who points out that "each style has something different to reveal to us about the culture and society of the people and country from which it originates" (p.24). The dance educator points out that when learning about different styles and dances from different parts of the world "you learn the physical techniques of those dance styles you become much more eclectic". She found her students are "able to adapt their bodies to the rhythm and musicality from right across the world" in her teaching and provided them with an enormous "movement vocabulary that gives them a vast source of ideas that they can pool, create and make from when they go out to teach". By providing a supportive and inclusive multicultural dance she moves away from the discourse of "we are all the same", which, as Allard (2006, p.326) rightly points out denies the possibility that there are "different knowledge and values systems that stand in contrast to those held by the hegemonic cultural group". For the dance educator, the inclusion of multicultural dance (Western and non-Western) gives her students a space to recognise "why people dance and what motivates them" it also offers a place and space of belonging as she confirms "it brings a sense of community, identity and a reflection of who they are collectively or as individuals".

\subsection{The inclusion of African dance within multicultural dance practice}

Within the four dance methodology units for dance (Arts Discipline Study 1, 2, 3 \& 4) and dance elective units at Deakin University teacher education courses (early childhood, primary and secondary), multicultural dance is at the forefront of preparing pre-service teachers to be culturally responsive in the classroom. According to the dance educator, "I have always taught cultural perspectives through dance. I teach about pedagogy in an integrated approach and am inclusive of different dances, genres and styles”. Within the unit Arts Discipline Study 3, the emphasis in this unit is on African dance. As an Australian dance practitioner who includes Aboriginal dance in her range of styles and genres across the 12 week semester, she has a strong focus on African dance which she learnt in various parts of Africa over the years. These include for example: Che Che Kule (Ghana), gumboot dance (South Africa), Eseni (a fisherwoman dance from West Nigeria), puberty dances (Kpatsa from Ghana), Elima (fertility from the Congo), Sosoni (from Senegal) and free style dance and improvisation like that of Kpanlogo a recreational dance from Ghana.

Similar to the teaching of music, dance in African societies are passed down through oral, aural and rote transmission. According to the dance educator, "the older generation is responsible for teaching dances and the music to the younger generation". Storytelling is an important part of African culture, this aspect the dance educator incorporates in her teaching. Potgieter (2006, p.24) argues that the use of storytelling "conveys messages of wisdom and truth" when teaching about African music and dance. The dance educator upholds "I go through that particular cultural perspective and I teach it from the way I was taught from my dance teacher in Ghana”. By being immersed in Ghanaian culture over two decades, regularly engaging in onsite professional development and dancing and mixing with Ghanaians in Ghana and in Melbourne she has an authentic voice to teach about dance in particular from Ghana. In her interview she points out that her method of teaching by learning under an indigenous person is far better than reading it from a book or viewing it from a video. She adds learning it with a local person is "a very authentic way of showing and telling...it is far better than reading it from the web”. I concur with her as a music educator teaching African music. The dance educator further points out "I go through the method like I was taught and talk about that very direct form of teaching method and that very specific dance style and the way it must be taught". It was apparent from her discussion the attention to detail she instils in her pre-service teachers and reiterates "the particular way a movement has to be done with this rhythm" as she confirms "I would teach it exactly as it was taught to me" which resonates with transmission model of dance teaching (Bolwell 1998\&Melchoir 2011).

As part of her African dance teaching the educator uses problem solving and enquiry based learning in her methodology. She comments:

I use the method of problem solving and group work so my cultural perspective is on the theme of the human body and how the body transforms itself from child to adult, so it is about puberty, sexuality, honouring one's body, acknowledging physical, biological physiological changes that children go through. That is my focus.

She points out where her theme is on a traditional puberty dance and identifies one from Ghana asserting, "I am knowledgeable and have experienced first-hand puberty dances from Ghana". Kpatcha is a traditional dance where the "movement patterns, group structures and transitions to the next phase of movement is strictly governed and supported by the rhythm of the drums that support the quality of movement" (Dreessens 2009b, p.30). By incorporating problem solving task cards in her workshops doing Kpatcha she says, "ok how can we get our Australian students to make up their own puberty dances having learnt this traditional model from 
Ghana"? This article does not focus on the details of her task cards (see Dreessens2009a) rather it highlights through multicultural dance such as Kpatcha issues of "celebrating what is beauty and how does the body move and how it is captured in photographic form, and what is beautiful in one culture is ugly in another are talked about". Through dance education, students engage in cross cultural dialogue, the dance educator states "we talk of how certain body parts need to be expressed...that honour certain parts of the body that represent strength, grace and beauty". She adds "I give them a traditional African Ghanaian model so that they can see how dance comes out of a given culture at a given moment in time and so that they can see that approach in the task card they look at for inspiration to create some new dance... an Australian puberty dance perhaps". The inclusion of African dances within her unit Arts Discipline Study 3 provides students with a wide range of dance styles and genres taking them out of their comfort zone to explore something new and different like that of African dance.

\section{Conclusion}

The focus of my discussion was not on multicultural policies, rather, I endeavoured to draw the reader's attention to the opportunities we can forge in Arts, in particular to dance education, by creating partnerships and relationships across cultures and societies through which we can promote multicultural inclusive practices in our educational settings. Australia is proud of its rich and varied array of the Arts within our diverse multicultural society. According to the Commonwealth of Australia (2003) document "Australian multiculturalism encourages Australians to support each other" and "encourages diversity in ways of thinking” (pp.7-8) which also extends to education at all levels. This article situated itself as part of my wider study Attitudes and perceptions of Arts Education Students: Preparing culturally responsive teachers across two continents (Australia and South Africa). I have only focused on interview data with the dance educator reporting on two themes in the area of the Arts. As tertiary educators we continue to be challenged in our preparation of pre-service teachers to be culturally responsive to such diversity. Hence, we need to adapt as well as adopt "a more critical multicultural approach to their [our] practice to meet the challenges posed both by societal diversity and the system in which they work" (Hagan \& McGlynn, 2004, p.245). I have argued elsewhere (Joseph, 2011) that by embracing a 'new' and 'different' music perhaps like that of African (South African) learners can recognise different music and culture not as "remote encounters but as appropriate, integral aspects of their lives" (Rose \& Kincheloe, 2003, p.134) given we live in a multicultural Australia. Similarly, dance education is a powerful platform to transmit and promote togetherness where understanding and respect is shared in dance practice. The complex issues of dance, culture and identity are interconnected forming a multicultural society in Australia.

As part of the unit Arts Discipline Study 3 which focuses on multicultural dance, the dance educator offers her students a wide range of experiences, bringing the rhythm of African both on campus (workshops) and off campus (community festivals and projects in schools). As it is not possible to take her students on a field trip to Africa during semester, she serves as a "curriculum resource, supporting the development of cross-cultural knowledge and skills" that she has learnt in Africa and brings her "experiences to bear on classroom interactions" (Bell, 2004, p.10). In other units where I have team taught with her (which is not the focus of this discussion) she places emphasises on the connection of music, dance and culture so her pre-service students recognise that in Africa, singing, drumming and dancing is as natural "as eating and drinking" (Walker, 2005, p.6) and is a shared communal experience. In her interview she spoke passionately about the strong link between music and dance particularly in Ghana where she undertakes most of her professional development as a percussionist and dancer. It was evident from her interview that students need to learn more than just one form of dance and style, they have to also have intercultural dialogue as "all dance forms have something to offer our students” according to Robinson and Domencic (2011, p.218). As part of Deakin University's teacher education courses I contend that 'moving to the rhythm of Africa' within Arts Discipline units, where authentic teaching and learning can be facilitated, is a powerful platform in which to share multicultural dance practice within tertiary education courses. By providing rich multicultural programs for our pre-service students in teaching and learning areas such as dance education, we can foster positive experiences that promote diversity and enhance intercultural and cross-cultural understanding.

\section{References}

Australian Curriculum, Assessment and Reporting Authority (ACARA). (2012a). The Arts. http://www.acara.edu.au/verve/_resources/Shape_of_the_Australian_Curriculum_The_Arts_-_Compressed. pdf

Australian Curriculum, Assessment and Reporting Authority (ACARA). (2012b). The Arts. http://www.acara.edu.au/arts.html

Albright, A. C. (2003). Channelling the 'Other': an embodied approach to teaching across cultures. Research in 
Dance Education, 4(2), 177-182. http://dx.doi.org/10.1080/1464789032000130390

Allard, A. (2006). 'A bit of a chameleon act': A case study of one teacher's understanding of diversity. European Journal of Teacher Education, 29(3), 319-340. http://dx.doi.org/10.1080/02619760600795155

Bell, M. (2004). Internationalising the higher education curriculum - Do academics agree? Proceedings of the 27th HERDSA Annual Conference, Transforming Knowledge into Wisdom, Miri, Sarawak (4-7 July 2004). http://www.herdsa.org.au/wp-content/uploads/conference/2004/PDF/P036-jt.pdf

Bolwell, J. (1998). Into the light: An expanding vision of dance education. In S. Shapiro (Ed.), In Dance, power and difference: Critical and feminist perspectives of dance education (pp.7-23). USA: Human Kinetics Publishers.

Buck, R. (2003). Teacher and dance in the classroom: 'So, do I need my tutu?' PhD diss., University of Otago, New Zealand.

Burbules, N. C. (1997). A grammar of difference: some ways of rethinking difference and diversity as educational topics. Australian Educational Researcher, 24(1), 97-116. http://dx.doi.org/10.1007/BF03219643

Chappell, K., Craft, A., Rolphe, L., \& Jobbins, V. (2009). Dance partners for creativity: choreographing space for co-participative research into creativity and partnership in dance education. Research in Dance Education, 8(1), 177-197. http://dx.doi.org/10.1080/14647890903324147

Commonwealth of Australia. (2003). Multicultural Australia: United in Diversity, Canberra, ACT: Department of Communications, Information Technology and the Arts.

Craig, C. J. (2009). Research in the Midst of Organized School Reform: Versions of Teacher Community in Tension. American Educational Research Journal, 46(2), 598-619. http://dx.doi.org/10.3102/0002831208330213

Csikszentmihalyi, M. (1990). Flow: The psychology of optimal experience. New York: Harper \& Row.

Deakin University Handbook. (2012a). ECA431 - Arts Education Discipline Study 12012. http://www.Deakin.edu.au/current-students/courses/unit-search.php?entunit=eca431\&entkeyword=Keywor $\mathrm{d} \&$ year $=2012 \&$ submit $=\mathrm{Go}$

Deakin University handbook. (2012b). Course Search: ECA 433 Arts Discipline Study 3, http://www.Deakin.edu.au/current-students/courses/unit-search.php?entunit=eca433\&entkeyword=Keywor $\mathrm{d} \&$ year $=2012 \&$ submit $=\mathrm{Go}$

Dinham, J. (2011). Delivering Authentic Arts Education. Melbourne: Cengage Learning Australia.

Dreessens, J. (2009a). Cross-Cultural Dance Task Cards. In Living Music \& Dance Handbook (pp.51-55). Living Music \& Dance Conference, Preston, Victoria

Dreessens, J. (2009b). KPATSA - Teaching traditional dance and rhythm from Ghana. In Living Music \& Dance Handbook (pp.30-35). Living Music \& Dance Conference, Preston, Victoria

Duncan, A. (2011). Foreword, Reinvestigating in Arts Education, http://www.pcah.gov/sites/default/files/photos/PCAH_Reinvesting_4web.pdf

Dunne, C. (2011). Developing an intercultural curriculum within the context of the internationalisation of higher education: terminology, typologies and power. Higher Education Research \& Development, 30(5), 609-622. http://dx.doi.org/10.1080/07294360.2011.598451

Gareis, E. (1995). Intercultural friendship: A qualitative study. Landam, MD: University Press of America.

Greiman, B. C, \& Covington, H. K. (2007). Reflective Thinking and journal writing: Examining student teachers' perceptions of preferred reflective modality, journal writing outcomes, and journal structure. Career and Technical Education Research, 32(2), 115-139. http://dx.doi.org/10.5328/CTER32.2.115

Guba, E. G., \& Lincoln, Y. S. (1981). Effective evaluation. San Francisco: Jossey-Bass Publishers.

Guskey, T. (2002). Professional Development and Teacher Change. Teachers and Teaching: theory and practice, 8(3/4), 381-391. http://dx.doi.org/10.1080/135406002100000512

Hagan, M., \& McGlynn, C. (2004). Moving barriers: promoting learning for diversity in initial teacher education. Journal of Intercultural Education, 15(4), 243-252. http://dx.doi.org/10.1080/1467598042000262545

Hayes, D. (2010). Young people and school. In R. Connell, C. Campbell, M. Vickers, A. Welch, D. Foley, N. 
Bagnall, and D. Hays (Eds.), Education, Change and Society (pp.1-20). South Melbourne: Oxford University Press.

Hong, T. (2000). Developing dance literacy in the postmodern: An approach to curriculum. Paper presented at Dancing in the Millennium, July 2000, Washington DC.

Imel, S. (2000). Change: Connections to Adult Learning and Education, ERIC Digest No.221. http://www.cete.org/acve/textonly/docgen.asp?tbl=digests\&ID=106

Kerr-Berry, J. (2004). The skin we dance, the skin we teach: Appropriation of black content in dance education. Journal of Dance Education, 4(2), 45-47. http://dx.doi.org/10.1080/15290824.2004.10387255

Jorritsma, M. (2008). What is African music? The Talking Drum, 29(1), 22-24.

Joseph, D. (2002). Umoja: teaching African music to generalist teacher education students. In J. Callaghan and J. Rosevear (Eds.), Research matters: linking outcomes with practice, proceedings of the XXIVth annual conference (pp. 86-98). Australian Association for Research in Music Education (AARME): Melbourne.

Joseph, D. (2003). An African music odyssey: introducing a cross-cultural music curriculum to Australian primary teacher education students. Journal of the International Society for Music Education, 2, 98-111.

Joseph, D. (2005). Travelling drum with different beats: experiencing African music and culture in Australian teacher education. Teacher Development: an International Journal of Teachers' Professional Development, 9(3), 287-300.

Joseph, D. (2006). Cultural understanding: rethinking music teacher education in a multicultural Australia. In W. Sims and R. Tahir (Eds.), Proceedings of the 27th World Conference of the International Society for Music Education (pp. 621-646). International Society for Music Education: Nedlands, WA.

Joseph, D. (2009). Masakhane: musical understanding in African music. In W. Baker, (Ed.), Proceedings of the XVIIth National Conference (pp.96-102). Australian Society for Music Education Incorporated: Launceston, Tasmania.

Joseph, D. (2011). Cultural Diversity in Australia: Promoting the Teaching and Learning of South Africa music. Australian Journal of Music Education, 1, 42-56.

Loughran, J., Mulhall, P., \& Berry, A. (2004). In search of pedagogical content knowledge in science: developing ways of articulating and documenting professional practice. Journal of Research in Science Teaching, 41(4), 370-391. http://dx.doi.org/10.1002/tea.20007

Mansouri, F., Jenkins, L., Leach, M., \& Walsh, L. (2009). Building Bridges: Creating a culture of diversity. Melbourne University Publishing: Victoria, Australia.

Merton, J. M. (2011). Multicultural Teacher Education: Identity and Difference in New Zealand. PhD diss., Deakin University, Melbourne, Australia.

Melchior, E. (2011). Culturally responsive dance pedagogy in the primary classroom. Research in Dance Education, 12(2), 119-135. http://dx.doi.org/10.1080/14647893.2011.575223

Mills, G. R. (1994). Umfundalai: One technique, three applications. Journal of Physical Education, Recreation and Dance, 65(5), 36-38. http://dx.doi.org/10.1080/07303084.1994.10606915

Miya, F. (2003). Appreciating Formal Africa Music. The Talking Drum, 20(2), 2-5.

Multicultural Arts Victoria. (2011). About Multicultural Arts Victoria. http://www.multiculturalarts.com.au/about.shtml

Multicultural Arts Victoria Annual Report. (2010). http://www.multiculturalarts.com.au/pdfs/agr2010.pdf

Mushi, S. (2004). Multicultural competencies in teaching: a typology of classroom activities. Intercultural Education, 15(2), 179-195. http://dx.doi.org/10.1080/1467598042000225032

Nieto, S. (1992). Affirming Diversity: The Sociopolitical Context of Multicultural Education. White Plains, New York: Longman.

Oerhle, E., \& Emeka, L. (2003). Thought systems informing the musical arts. In A. Herbst, M. Nzewi and K. Agawu (Eds.), Musical arts in Africa: theory, practice and education (pp.38-51). University of South Africa: Pretoria, South Africa.

Pope, J., \& Doyle, S. (2006). Strengthening local communities: Arts in Community Settings. Victoria: Arts Victoria. 
Potgieter, H. (2006). "Story catching” in Arts and Culture. The Talking Drum, 26(2), 24-27.

Rose, K., \& Kincheloe, J. L. (2003). Arts, Culture \& Education. New York: Peter Lang Publishing.

Richards, H., Brown, A., \& Forde, T. (2007). Addressing diversity in schools: Culturally responsive pedagogy. Teaching Exceptional Children, 23(3), 63-68.

Risner, D. (2007). Critical social issues in dance education research. In L. Bresler (Ed.), International Handbook of Research in Arts education (pp.965-982). Dordrecht, NL: Springer. http://dx.doi.org/10.1007/978-1-4020-3052-9_66

Robinson, D., \& Domenici, E. (2010). From inclusion to integration: intercultural dialogue and contemporary university dance education. Research in Dance Education, 11(3), 213-221. http://dx.doi.org/10.1080/14647893.2010.527324

Russell-Bowie, D. (2009). MMAD about the arts. Australia: Pearson Prentice Hall.

Stodolsky, S. S., \& Grossman, P. L. (2000). Changing students, changing teaching. Teachers College Record, 102(1), 125-173. http://dx.doi.org/10.1111/0161-4681.00050

Ubuntu. (2012). Ubuntu Philosophy, http://en.wikipedia.org/wiki/Ubuntu

Victorian Essential learning Standards. (VELS) (2011). Introduction to the Arts. http://vels.vcaa.vic.edu.au/arts/intro.html

Victorian Essential learning Standards. (VELS) (2011). Approaches to the Arts. Introduction to the Arts. http://vels.vcaa.vic.edu.au/arts/approaches.html

Victorian Multicultural Commission. (2009). Population and migration. http://www.multicultual.vic.gov.au/web24/vmc.nsf/headingpagesdisplay/population+and+migration

Villegas, A. M., \& Lucas, T. (2002). Educating culturally responsive teachers: A coherent approach. Albany, New York: State University of New York Press.

Volk, T. M. (2004). Music, Education and Multiculturalism. Oxford: Oxford University Press.

Wade, R. (1998). Brick walls and breakthroughs: Talking about diversity with white teacher education students'. Social Education, 62(2), 84-87.

Walker, R. (2005). We all came out of Africa singing and dancing and we have been doing it ever since. Research Studies in Music Education, 24(4), 4-16. http://dx.doi.org/10.1177/1321103X050240010101

Wild Moves. (2012). Centre for drum and dance. http://wildmovesevents.blogspot.com.au/search?updated-min=2011-01-01T00:00:00-08:00\&updated-max= 2012-01-01T00:00:00-08:00\&max-results $=22$

Wilkinson, D. (2000). The Researcher's Toolkit: The complete guide to practitioner research. London: New York: Routledge.

Zijlma, A. (2011). Facts about Africa, http://goafrica.about.com/od/africatraveltips/a/africafacts.htm

${ }^{\mathrm{i}}$ The word Ubuntu is a sub-Saharan African ethic or ideology focusing on people's allegiances and relations with each other. The word has its origin in the Bantu languages of Southern Africa. Ubuntu is seen as a traditional African concept—-"humanity towards others," or "I am because we are," or "A person 'becomes human' through other persons", or also, "A person is a person because of other persons". Another translation could be: "The belief in a universal bond of sharing that connects all humanity." (see Ubuntu 2012.)

\section{(cc) BY}

This work is licensed under a Creative Commons Attribution 3.0 License. 